adsint, attamen non tales sunt quales in Anacardiaceis observantur. Planta locus systematicus, cum flores nondum cogniti sint, mihi plane dubius remanet.'

In the Botany of the Biologia Centrali-Americana, having no specimens before me, I could do no more than record the name; and it was not till I90I, when Kew acquired specimens of the male of my $J$. mollis, and fruiting specimens of what I take to be the original $J$. adstringens, that I was able to throw a little more light on the subject by publishing (Hooker's Icones Plantarum, t. 2722 et 2723) figures of the structure, so far as the material permitted. This was done with the idea of directing attention to this singular genus, and of obtaining better specimens. It resulted in Dr. J. N. Rose, Assistant Curator of the Botanical Collections of the United States National Museum at Washington, generously offering to procure for me the privilege and advantage of examining the whole of the material belonging to that Institution, collected partly by himself, partly by Messrs. Pringle, Nelson, Lumholtz, Hay, Langlassé and Hough, together with his notes. At the present time we are engaged on a fully illustrated monograph of the genus, including an account of its anatomy and organogeny by Dr. F. E. Fritsch; and in that we shall fully discuss its affinities. This preliminary communication, it is hoped, will bring us further material of some of the species; more female flowers especially are wanted to enable us to complete our researches. I may add that Dr. A. Engler, of Berlin, Dr. C. Mez, of Halle, and Dr. A. Zahlbruckner, of Vienna, have failed to find any of the original specimens collected by Dr. C. J. W. Schiede, the discoverer.

NOTE TO ARTICLE IN THE ANNALS OF BOTANY, VOL. XVI, NO. 63, SEPTEMBER, 1902, ON "THE "SADD" OF THE UPPER NILE.'

\title{
Grasses of the 'Sadd.'
}

At p. 5 or of the Annals of Botany, in the article above cited, Sir William Garstin, the Under-Secretary to the Government of Egypt, in the Public Works Department, was quoted by me as saying that a specimen of the 'umsoof' grass, Vossia procera, which had been sent to the British Museum, was there identified as Phragmites communis. And Sir William did not mention it anywhere in his report as being one of the components of 'Sadd'; nor, so far as I had 
observed, did Dr. Schweinfurth mention it in the works I quoted from. But it was difficult to believe that the botanists of the British Museum could have made the mistake imputed to them. After the article was published I read Sir Harry Johnston's 'The Uganda Protectorate,' and found in it a description of the 'Sadd,' in which, after describing the growth of the Papyrus plant, he says:-

'A long Phragmites reed, with fluffy-like plumes like the Pampas grass, grows out into the shallow water, and builds barriers into the stream which arrest the floating islands of papyrus; or this reed may form floating islands of its own. Papyrus may prosper so much on the floating islands, composed mainly of its own roots, that these roots may reach the thickness of a man's leg, and grow downwards twenty feet below the top of the floating islands.'

Next, my attention was drawn to the paper on 'The Botany of the Speke and Grant Expedition,' published in the Transactions of the Linnean Society, London, vol. xxix, in which, at p. 173, was found the following:

'19. Phragmites communis, Trin.; Kunth, Enum. Pl. i, 25. Arundo phragmitis, L., App. Speke's Journ. 653. Hab., from $4^{\circ} 55^{\prime}$ N. lat. and northward, Col. Grant! A cosmopolitan species.

' [Reed in Unyoro marshes, 2 Ist Sept. 1 862. Not in flower. 8 feet high, erect, round stem, tubular between the joints. Leaves 2 spans long, 2 inches broad at their bases, stiff, smooth, not filed at their edges or on their surfaces, alternate, their bases clasp the stem, and grow regularly in one plane from the right and left sides only.

'Native name and uses: "Mataetae." The flutes and whistles of the Waganda are made of this reed. It is said to grow as thick as the arm in Nyassa, $\mathbf{I}^{\circ} \mathrm{S}$. lat., where the natives make a fence of it. ... It extends in one great sea for $\mathbf{I}, \mathbf{I} 00$ miles north of $4^{\circ} 55^{\prime}$ N. lat.-J. A. G.].'

From all this it is clear that Sir William Garstin, or the officer under him who collected the specimens of the 'Sadd' plants which were sent to the British Museum, possibly owing to absence of inflorescence, failed to distinguish between the two large grasses which probably were growing together in the same 'Sadd.'

Phragmites communis is the largest grass indigenous to Britain; and in the Dehra Dún district, and other parts of British India, it covers square miles of swampy ground, and is commonly called Elephant or Tiger grass, from its size, 15 to 20 feet in height, or, 
perhaps, from affording shelter to those large animals. The vernacular name in the Dehra Dún is nál. It there grows on land which is submerged during floods as well as in actual swamp; and amongst it I have seen, drawn up by its shelter and support, the fern Asplenium (Anisogonium) esculentum, Presl., 9 to $\mathbf{2} 2$ feet high, with a subarborescent candex, 6 to $\mathbf{I} 2$ inches high. This is not the usual habit of the fern, which in the same locality, outside the nál, grows in clumps 3 to 4 feet high. Elsewhere in the Dún, it is a hedge-and-ditchrow plant.

\section{'Sudd' v. 'Sadd.'}

As to the pronunciation and spelling of the word 'sudd' or 'sadd,' the following is found in Sir Harry Johnston's book, vol. i. p. I 49. "The "Sudd" (which should really be spelt "sadd" 1_Schweinfurth first refers to it as "satt" or "sett") is, as most untravelled people now know, an extraordinary floating vegetable obstruction which collects in the waters of these equatorial lakes and rivers where the lake surface is sheltered from rough winds, and where the current of the river is sluggish. Papyrus clumps become detached by the action of the waves or floods, and, driven by the breeze into little groups, these roots become united below the surface of the water by the accretion of water-reed and other vegetable substances, so that in time a peaty mass is formed just below the surface of the water, from which the Papyrus continues to grow as from a soil.' (Then follows the passage quoted above, showing "the" part Phragmites communis plays in the formation of a 'Sadd' block.)

Though Sir Harry Johnston explained that the word 'Sadd' is Arabic, and said how it is to be pronounced, he did not tell us what it really means, or how it is otherwise used. But this has lately become known to people who are not acquainted with Arabic from contributions to the Press in connexion with the completion of the great dams across the Nile, which were alluded to at the outset of the article in the Annals of Botany to which this is a supplement. In a description of the works which were found necessary in the construction of the great dam at Assuan, I find mention of the considerable work 'done in connexion with sadds (sic) or temporary dams across three out of the five deep channels which cross the

1 "It is an Arabic word pronounced like the "sud" "in soapsuds"; but this is really a short sound of the vowel " a " in phonetic spelling.' 
line of the dam and carry the supply of the Nile during summer and winter.... The method adopted for dealing with these deep channels was to construct "sadds" across them upstream and downstream of the site of the dam; these sadds were then made sufficiently watertight to allow of the area between them being laid dry by pumping. It was necessary to make the sadds on one side of the dam of stones so as to stand the great rush of water: these sadds were made before the great rush of water, to a level of 5 mètres below high Nile, and on the north side of the dam. Thus, when the flood was subsiding, still water was easily obtained upstream of the sadd, and a sandbag sadd was commenced on the other side, so that the three channels were cleared by the end of the year.' And the word 'sadd,' as meaning a temporary or subsidiary dam, of earth or stone work, is found in other parts of the article now being quoted from. It seems probable the use of the word 'sadd,' as the name for the vegetable obstructions in the Upper Nile, was taken from the ordinary use of the word on lower parts of the river where irrigation has long been in vogue. The smallest kind of sadd is the two or three spadesful of earth with which the cultivator (in India at least) turns canal or rain water from one compartment of a field into another.

\section{The Clearing of the 'Sadd.'}

A recent number of the Geographical Journal contains a paper on the 'Sadd' of the White Nile, by Dr. Edward S. Crispin, explaining the method of opening up the true river bed employed by Major Matthews, who commanded the Sadd Expedition of $190 \mathbf{r}-2$. The first difficulty is to find the position of the river bed; this is done by probing, the depth suddenly increasing to $5_{5}$ to 20 feet. Next, the top growth, consisting mostly of Papyrus, is cut down or burnt. Men are then landed on the cleared surface, and the sadd cut along the river banks with saws; next transverse cuts are made, dividing the sadd into blocks convenient for the steamer to tear out. The bows of the steamer are run into the block, and the loop of a steel hawser, both ends of which are made fast to the steamer, is passed over the bows and trodden into a trench cut on the surface of the block. The steamer then goes full speed astern, men standing on the hawser to keep it in position, and after a number of trials the block is torn away and cast adrift to float downstream, where it is gradually disintegrated. 


\section{Plants allied to the Ambatch.}

From The Botany of the Speke and Grant Expedition; Trans. Linn. Soc. vol. xxix, p. $5^{8}$, the following may be taken:-

'36. Eschynomene Schimperi, Hochst., in Hb. Schimp. Abyss. No. 202 ; A. Rich. Fl. Abyss. i. 202 ; Baker in Fl. Trop. Africa, ii. 146 .

' Hab. By the Nile, Nov. 1862, Col. Grant. This is a form of the Abyssinian plant, from which it may possibly prove distinct when more ample material shall have been obtained.

[. . . A wide-spreading branched tree, 20 feet high, in or by water at Unyoro, with the Papyrus. . . . The wood is white, and streaked with black longitudinally. It is so remarkable for lightness that I measured a $\log 4 \frac{1}{2}$ feet long and $I_{5}$ inches in mean circumference, and it weighed only $2 \frac{1}{2}$ pounds. It is a most useful wood to the inhabitants, as they make floats, levers for carrying their loads, blocks to cut upon, bolts for their doorways; and for shields no wood can equal it for toughness and lightness, two qualities requisite in the shield of the Uganda people. It would make admirable sun hats.J. A. G.]

'37. AE. indica, Linn.; DC., Prod. ii. 320 ; Baker in Fl. Trop. Africa, ii. 167 ; Wight Ic. t. 405 .

'Hab. Unyoro, Sept. I 862 , Col. Grant! Widely spread in Trop. Africa and Asia.

['Native name "m'neenge" (Zanzibar). Plentiful everywhere: at $5^{\circ} \mathrm{S}$. lat.; in the dry season (September) its dead stem was prostrate on the dried mud; but at $2^{\circ} \mathrm{N}$. lat., in the same month it was in leaf and fruit. Though only growing straight to 6 or 7 feet high, the thickest part of the stem measures large in proportion, 16 inches in circumference.-J. A. G.']

C. W. HOPE. 


\section{$2 \mathrm{BHL}$ Biodiversity Heritage Library}

Hope, C. W. 1903. "Note to article in the annals of botany, vol. xvi, no. 63, September, 1902, on 'the "Sadd" of the upper Nile'." Annals of botany 17, 446-450. https://doi.org/10.1093/oxfordjournals.aob.a088926.

View This Item Online: https://www.biodiversitylibrary.org/item/235015

DOI: https://doi.org/10.1093/oxfordjournals.aob.a088926

Permalink: https://www.biodiversitylibrary.org/partpdf/318724

\section{Holding Institution}

Smithsonian Libraries

\section{Sponsored by}

Biodiversity Heritage Library

\section{Copyright \& Reuse}

Copyright Status: Not in copyright. The BHL knows of no copyright restrictions on this item.

This document was created from content at the Biodiversity Heritage Library, the world's largest open access digital library for biodiversity literature and archives. Visit BHL at https://www.biodiversitylibrary.org. 